\title{
Recombinant Interferon Gamma Augments Phagocyte Superoxide Production and X-Chronic Granulomatous Disease Gene Expression in X-Linked Variant Chronic Granulomatous Disease
}

\author{
R. Alan B. Ezekowitz, Stuart H. Orkin, and Peter E. Newburger \\ Division of Hematology/Oncology and the Howard Hughes Medical Institute, The Children's Hospital, and the Department of \\ Pediatrics, Harvard Medical School, Boston, Massachusetts 02115; and Department of Pediatrics, \\ University of Massachusetts Medical School, Worcester, Massachusetts 01605
}

\begin{abstract}
We examined the potential of interferon gamma (IFN-gamma) to ameliorate the physiologic defect of chronic granulomatous disease (CGD) by studying its effects on CGD phagocyte superoxide generation, NADPH oxidase kinetics, cytochrome $b_{559}$ content, and expression of X-CGD (the gene for the Xlinked disease). Granulocytes and macrophages from three patients in two kindreds with "variant" X-linked CGD (i.e., with very low, but detectable, baseline superoxide-generating activity) responded to IFN-gamma with enhanced nitroblue tetrazolium reduction and two- to eightfold increases in superoxide generation. IFN-gamma did not augment the respiratory burst activity of phagocytes from patients with "classic" CGD (i.e., no detectable baseline superoxide generation) or autosomal variant CGD. Incubation of a responding patient's granulocytes with IFN-gamma nearly doubled the maximal velocity for the NADPH oxidase, but did not change its abnormal Michaelis constant. Although the interferon-treated CGD granulocytes produced superoxide at a rate $40 \%$ of normal, the cytochrome $b$ spectrum remained undetectable. IFN-gamma treatment of cultured monocytes from an IFN-gamma-responsive CGD patient increased the steady state level of RNA transcripts from the X-CGD gene from barely detectable up to $\sim 5 \%$ of normal.
\end{abstract}

\section{Introduction}

Phagocytic cells, such as macrophages and polymorphonuclear leukocytes (PMN), produce reactive oxygen intermediates with microbicidal, tumoricidal and inflammatory effects $(1,2)$. The initial step in their formation is the one-electron reduction of oxygen to superoxide, catalyzed by a membrane-associated NADPH oxidase. The enzyme system is inactive in resting cells, but is rapidly activated upon exposure to a variety of particulate and soluble stimuli that act though several alternative pathways of transmembrane signal trans-

This work was presented in part at the 28th annual meeting of the American Society of Hemotology, San Francisco, CA, December 1986, and published as an abstract (1986. Blood. 68:82. [Abstr.])

Address correspondence to Dr. P. E. Newburger, Department of Pediatrics, University of Massachusetts Medical School, 55 Lake Ave. North, Worcester, MA 01605.

Received for publication 18 February 1987 and in revised form 10 June 1987.

J. Clin. Invest.

(c) The American Society for Clinical Investigation, Inc.

0021-9738/87/10/1009/08 $\$ 2.00$

Volume 80, October 1987, 1009-1016 duction (3-5). Regulation of NADPH oxidase activity includes not only activation, but also processes of priming (6) and deactivation (7).

In chronic granulomatous disease (CGD), ${ }^{1}$ phagocytes fail to produce superoxide and its oxygen metabolites $(8,9)$. Thus, PMN and macrophages from these patients ingest particles and degranulate normally, but fail to kill microorganisms (10). This defect in host defense results in recurrent, and sometimes fatal, purulent infections beginning early in childhood (11). The disease exhibits heterogeneity of inheritance, with the majority of cases being $\mathrm{X}$-linked and a minority, autosomal recessive (12). In most (13), but not all (14), X-linked kindreds, patients' phagocytes lack spectrally detectable cytochrome $b_{559}$, a heme-containing protein that has been proposed as a critical terminal component of the oxidase system $(15,16)$. Recently, molecular cloning of the X-CGD gene (the gene for the X-linked disease) and its cDNA has been accomplished (17). The protein product of the X-CGD gene is predicted to be a 58-kd basic polypeptide that contains several potential glycosylation sites and bears no homology to known proteins, including cytochromes. Antibodies raised to a synthetic peptide derived from the predicted sequence assign the in vivo gene product as a glycosylated $90-\mathrm{kd}$ membrane protein (18). This species forms part of the neutrophil cytochrome $b_{559}$ heterodimer, which consists of the $90-\mathrm{kd}$ glycoprotein and a 22-kd nonglycolsylated polypeptide (19). Both components are absent from PMN of patients with X-linked CGD (20). In contrast, PMN from most patients with the autosomal recessive disease contain normal cytochrome $b_{559}$, but lack a soluble activation factor (21) and fail to phosphorylate a protein with an apparent molecular weight of 44,000 (22). The molecular basis for this form of the disease remains unknown.

In addition to these "classic" forms of CGD, several "variants" have been reported, all with decreased but detectable neutrophil $\mathrm{O}_{2}^{-}$production (23-28). Most of these patients presented later in life, with milder clinical disease, than classic CGD patients. Their neutrophils showed altered NADPH oxidase kinetics, which consists of an elevated Michaelis constant $\left(\mathrm{K}_{\mathrm{m}}{ }^{\text {app }}\right.$, reflecting decreased affinity for NADPH) with (24) or without $(23,25,26)$ a decreased maximum velocity $\left(\mathrm{V}_{\max }\right)$. In most of the X-linked cases $(23,24,28)$ cytochrome $b_{559}$ was undetectable, but in one of the X-linked (27) and the autosomal recessive cases $(25)$ the cytochrome content was normal. Most likely, these variants represent the currently detectable end of a spectrum of X-CGD gene expression, analogous to the range of beta thalassemia or hemophilia A.

1. Abbreviations used in this paper: $\mathrm{CGD}$, chronic granulomatous disease; IFN-alpha, -beta, -gamma, interferons alpha, beta, gamma; $\mathrm{K}_{\mathrm{m}}{ }^{\text {app }}$, Michaelis constant; NBT, nitroblue tetrazolium. 
Previous work in our laboratory (Newburger, P. E., S. H. Orkin, and R. A. B. Ezekowitz. Unpublished data) has shown an increase in steady state levels of RNA derived from the $\mathrm{X}$-CGD gene in normal cultured monocyte-derived macrophages incubated with interferon gamma (IFN-gamma). Also, the difference in superoxide production and substrate affinity between the NADPH oxidases of CGD variant and normal neutrophils is similar to that between the NADPH oxidases of resting and IFN-gamma-activated cultured macrophages (29, 30). Further, Berton et al. have recently demonstrated the ability of IFN-gamma to enhance respiratory burst activity in neutrophils as well (31). We therefore explored the potential of IFN-gamma to ameliorate the physiologic defect of CGD by studying its effects on CGD phagocyte superoxide generation, NADPH oxidase kinetics, cytochrome $b_{559}$ content, and $\mathrm{X}$-CGD gene expression.

\section{Methods}

Media and reagents. RPMI 1640 was obtained from Grand Island Biological Co., Grand Island, NY; cytochrome $c$, phorbol myristate acetate (PMA), nitroblue tetrazolium (NBT), superoxide dismutase, Triton X-100, Triton X-114, and zymosan, from Sigma Chemical Co., St. Louis, MO; ficoll 400 and dextran 500 from Pharmacia Fine Chemicals, Piscataway, NJ; and sodium hypaque, 50\%, from Winthrop Laboratories, New York, NY.

Recombinant human INF-alpha, -beta, and -gamma were obtained from Genentech, Inc., San Francisco, CA, and from Dr. P. Trown, Hoffmann-La Roche, Inc., Nutley, NJ; all contained < 2 EU endotoxin/mg interferon ( $<1 \mathrm{EU} / 10^{7} \mathrm{U}$ interferon) as determined by limulus amoebocyte lysate assay. Interferon stock solutions of $10^{6}$ and $10^{2}$ $\mathrm{U} / \mu \mathrm{l}$ in RPMI 1640 were stored at $-80^{\circ} \mathrm{C}$ and $4^{\circ} \mathrm{C}$, respectively, and the latter diluted to final concentrations immediately before use.

Cells. Peripheral venous blood in acid-citrate-dextrose anticoagulant was obtained from CGD patients, normal volunteer donors, and the granulocyte and mononuclear cell fractions isolated by dextran sedimentation and Ficoll-Hypaque centrifugation (32). Procedures and consent forms were approved by the University of Massachusetts Medical School and The Children's Hospital Committees on the Protection of Human Subjects in Research.

Clinical and biochemical descriptions of variant CGD patients $\mathrm{RaJ}, \mathrm{ReJ}$, and RQ have recently been published (28); $\mathrm{RaJ}$ and $\mathrm{ReJ}$ are brothers, with granulocytes showing virtually identical biochemical characteristics. Patient BS has variant CGD (based on uniformly trace-positive granulocytes on NBT slide tests and 5\% normal rate of PMA-stimulated superoxide production) and probable autosomal recessive inheritance (based on normal granulocyte cytochrome $b$ content and normal parental NBT slide tests and quantitative superoxide production). Patients MD, TB, JW, and JM have classic X-linked CGD, based on absent NBT reduction and superoxide generation, undetectable cytochrome $b$, and maternal NBT slide tests showing a mosaic population of normal and inactive granulocytes. Patient $L N$ has classic autosomal recessive CGD based on absent NBT reduction and superoxide generation, normal granulocyte cytochrome $b$, and normal maternal NBT slide tests.

Monocytes were further purified by adherence to polystyrene tissue culture wells (Falcon Div., Becton-Dickinson \& Co., Oxnard, CA) at $37^{\circ} \mathrm{C}$ in RPMI 1640 medium in the absence of serum for $1 \mathrm{~h}$. The nonadherent cells, mainly lymphocytes, were then washed off, leaving adherent cells that were $90-95 \%$ nonspecific esterase positive. Cells were either assayed at that time or cultivated further in $10 \%$ heat-inactivated autologous serum with or without $100 \mathrm{U} / \mathrm{ml}$ of recombinant human IFN-gamma or $1,000 \mathrm{U} / \mathrm{ml}$ each of recombinant human IFNalpha and -beta.

Granulocytes were further purified by hypotonic lysis of erythrocytes (32). Granulocytes were cultivated in Krebs-Ringer phosphate buffer with $5 \mathrm{mM}$ glucose (32) with or without $100 \mathrm{U} / \mathrm{ml}$ of IFNgamma for $40 \mathrm{~min}$ to $4 \mathrm{~h}$ at $37^{\circ} \mathrm{C}$ in either polystyrene tissue culture wells (for superoxide assays) or polypropylene tubes (for superoxide assays, NADPH oxidase kinetics, and cytochrome $b$ assays). The results for superoxide assays were identical for each vessel; when cultured in polystyrene, both adherent and nonadherent cells were used in subsequent assays.

Assays. For NBT-reduction assays, granulocytes or macrophages were cultured as above, but on sterile glass coverslips, then incubated for $15 \mathrm{~min}$ at $37^{\circ} \mathrm{C}$ in Krebs-Ringer phosphate buffer with $5 \mathrm{mM}$ glucose containing NBT and either PMA $(100 \mathrm{ng} / \mathrm{ml})$ or opsonized zymosan $(10 \mu \mathrm{g} / \mathrm{ml})$ as previously described (33). Two investigators examined the coverslips by phase microscopy, and scored NBT reduction in each experimental group on a semiquantitative five-point scale $(0$ to ++++$)$. Scoring was confirmed by a third independent observer, familiar with the NBT method and blinded to the experimental design.

Superoxide generation was measured by a discontinuous assay of superoxide dismutase-inhibitable ferricytochrome $c$ reduction, as previously described (33) except for the use of PMA $(100 \mathrm{ng} / \mathrm{ml})$ or serum-opsonized zymosan $(1 \mathrm{mg} / \mathrm{ml})$ as stimulants.

Granulocyte NADPH oxidase activity and kinetics were measured as NADPH-dependent superoxide dismutase-inhibitable cytochrome $c$ reduction at $28^{\circ} \mathrm{C}$ in particulate fractions from PMA-stimulated neutrophils (34-36). The NADPH concentration was varied from 0.1 to $5 \mathrm{mM}$ and the data analyzed by the method of Lineweaver and Burk (37). Before PMA stimulation, the PMN were incubated (as above) for $3 \mathrm{~h}$ at $37^{\circ} \mathrm{C}$ with or without IFN-gamma $500 \mathrm{U} / \mathrm{ml}$.

Cytochrome $b_{559}$ content was measured in whole granulocytes by anaerobic-aerobic and dithionite-aerobic difference spectroscopy of cell suspensions in phosphate-buffered saline with and without $0.2 \%$ (vol/vol) Triton X-100, as previously described (35). Cytochrome $b_{559}$ was also extracted and concentrated from cell sonicates with Triton $\mathrm{X}-114$ (38) and then spectrophotometrically assayed as above.

Monocyte-derived macrophages for messenger RNA (mRNA) analysis were cultured in plastic tissue culture wells, as previously described (33), with or without IFN-gamma $100 \mathrm{U} / \mathrm{ml}$. At day 8 of culture, cells were scraped directly into $6 \mathrm{M}$ guanidine $\mathrm{HCl}$, and RNA was extracted by ethanol precipitation from guanidine $\mathrm{HCl}$ as described by Ginsburg et al. (39). Parallel wells were assayed for NBT reduction to confirm the interferon effect for each experiment. Total cellular RNA was examined by Northern blot analysis (40), using randomly primed $(36,41)$ complementary DNA probes for sequences from X-CGD (17) and constitutively expressed genes for phosphoglycerate kinase (42).

\section{Results}

NBT reduction. The histochemical NBT test semiquantitatively measures respiratory burst activity in individual cells $(33,35)$. As shown in Table I, PMN and macrophages from patients with variant $C G D$, both $X$-linked and autosomal recessive, responded with NBT reduction that was detectable, but below normal. The cells from the X-linked variant CGD patients showed augmented responses after incubation with IFN-gamma. In contrast, phagocytes from the classic CGD patients, which showed no detectable NBT reduction, and from the autosomal variant did not increase NBT reduction after IFN-gamma treatment. Normal macrophages showed the expected augmentation. Normal granulocytes did not change their response (perhaps because it was already maximal in this assay system). Cell-by-cell analysis showed that the populations of cells responded uniformly, i.e., no subpopulations of high- or nonresponders were present.

Similar responses were observed with opsonized zymosan as the phagocytic cell stimulus. Fig. 1 presents photomicro- 
Table I. PMA-stimulated NBT Reduction by CGD and Normal Phagocytes

\begin{tabular}{|c|c|c|c|c|c|}
\hline & \multirow[b]{2}{*}{ Patient } & \multicolumn{2}{|l|}{ PMN } & \multicolumn{2}{|c|}{ Macrophages } \\
\hline & & $-\mathrm{IFN} \gamma$ & $+\mathrm{IFN} \gamma$ & $-\mathrm{IFN} \gamma$ & $+\mathrm{IFN} \gamma$ \\
\hline \multicolumn{6}{|c|}{ X-linked CGD } \\
\hline \multirow[t]{3}{*}{ Variant } & RaJ & + & +++ & + & +++ \\
\hline & $\operatorname{ReJ}$ & + & +++ & + & +++ \\
\hline & RQ & + & ++ & + & ++ \\
\hline \multirow[t]{4}{*}{ Classic } & TB & 0 & 0 & 0 & 0 \\
\hline & MD & 0 & 0 & 0 & 0 \\
\hline & $\mathbf{J M}$ & 0 & 0 & 0 & 0 \\
\hline & JW & 0 & 0 & ND & ND \\
\hline \multicolumn{6}{|c|}{ Autosomal CGD } \\
\hline Variant & BS & + & + & + & + \\
\hline Classic & LN & 0 & 0 & 0 & 0 \\
\hline Normal & & ++++ & ++++ & ++ & ++++ \\
\hline
\end{tabular}

Groups were assigned values on a 0 to ++++ scale on the basis of the scoring on NBT slide tests of 100 cells per group by two readers, as described in Methods. IFN $\gamma$, IFN-gamma.

graphs of NBT slides of PMN (top, $a-d$ ) and macrophages (bottom, $e-h$ ) from X-linked variant CGD patient RaJ (left; $a$, $c, e, g$ ) and a normal control (right; $b, d, f, h$ ). IFN-gamma incubation dramatically increases the amount of NBT reduction, seen as dark formazan associated with ingested zymosan particles, in the CGD PMN and macrophages. Its effect is also evident in normal macrophages but not PMN, which are intensely strained even without the interferon.

The effect of IFN-gamma was first observed on granulocytes after 40 min exposure and was maximal at $2 \frac{1 / 2}{2}$ to $4 \mathrm{~h}$. Thereafter, cell viability began to fall off. The earliest detectable response of monocyte-derived macrophages to IFNgamma was after $36 \mathrm{~h}$ of incubation, with maximal responses reached by $48-72 \mathrm{~h}$ and then maintained for $8 \mathrm{~d}$ in culture. Macrophages cultivated with IFN-gamma displayed other interferon effects, including enhanced spreading and decreased mannose receptor activity, compared with untreated controls (data not shown).

Incubation of PMN and macrophages with IFN-alpha and -beta produced no augmentation of NBT reduction (data not shown).

Superoxide production. We next quantitatively examined superoxide generation by a spectrophotometric assay of superoxide dismutase-inhibitable cytochrome $c$ reduction. Table II shows that superoxide production followed the same pattern as NBT reduction: IFN-gamma augmented the responses in Xlinked variant, but not classic, CGD phagocytes, and similarly affected normal macrophages. The proportional increases in superoxide generation were at least two- to threefold for PMN and two- to eightfold for macrophages; the exact relative change could not be determined because baseline responses were undetectable for most of the CGD cells. Similar results were obtained with opsonized zymosan as the stimulus (data not shown).

Normal PMN did not show enhanced superoxide generation in response to IFN-gamma, again probably due to the maximum stimulation provided by PMA and opsonized zy- mosan. Berton et al. detected such augmentation only with suboptimal stimuli such as chemotactic peptide or very low dose PMA (31). They, too, noted a loss of the IFN-gamma effect with higher doses of PMA.

In the absence of a respiratory burst stimulus, there was no detectable superoxide production by PMN or macrophages, whether incubated with or without IFN-gamma. That is, as previously observed (43), IFN-gamma does not by itself activate the superoxide-generating system.

IFN-alpha and -beta did not augment superoxide responses in any of the cells tested (data not shown).

NADPH oxidase kinetics. To elucidate the mechanism for the increase in superoxide production induced by IFNgamma, we examined its effect on the kinetics of granulocyte NADPH oxidase. Only patients RaJ and ReJ could donate enough blood and had shown sufficient baseline granulocyte superoxide-generating activity to provide the cell numbers and unenhanced enzyme activity necessary for kinetic studies. As shown in Fig. 2, Lineweaver-Burk analysis revealed linear relationships ( $r>0.96$ by simple linear regression) between the reciprocals of the rate of superoxide production by particulate fraction from PMA-stimulated granulocytes and the reciprocals of NADPH concentrations. Table III presents the calculated $\mathrm{V}_{\max }$ and $\mathrm{K}_{\mathrm{m}}$ app of the CGD and normal oxidases. As previously reported (28), the $\mathrm{V}_{\max }$ for NADPH oxidase from the variant CGD granulocytes was $<10 \%$ that from normal cells. Incubation for $4 \mathrm{~h}$ in IFN-gamma nearly doubled the maximal velocity for the CGD oxidase, but did not affect the already high velocity of the normal enzyme (a response pattern parallel to that described above for intact cells). IFN-gamma only slightly lowered the abnormal $\mathrm{K}_{\mathrm{m}}{ }^{\text {app }}$ of the CGD enzyme.

Although the interferon-treated CGD granulocytes produced superoxide at a rate $40 \%$ of normal, cytochrome $b_{559}$ remained spectrophotometrically undetectable. As illustrated in Fig. 3, the characteristic cytochrome $b$ difference spectrum of intact granulocytes was not observed either with or without IFN-gamma, in an assay capable of detecting the spectrum at an intensity $5 \%$ that of normal cells. Addition of Triton X-100 ( $0.02 \%$ final concentration) enhanced the $474 \mathrm{~nm}$ (myeloperoxidase) peak, but did not reveal any cytochrome $b$, nor did extraction with Triton X-114 (data not shown). Anaerobicaerobic difference spectra showed similar baseline drift but no absorption peaks (data not shown). Quantitive measurement of cytochrome $b$ from the absorption spectra revealed no detectable content (i.e., $<10 \mathrm{pg} / \mathrm{mg}$ protein) in PMN from patients RaJ, ReJ, and RQ either with or without IFN-gamma treatment. Normal PMN contained 105 and $97 \mathrm{pg} / \mathrm{mg}$ protein with and without IFN-gamma, respectively.

$X$-CGD gene transcripts. As shown in Fig. 4, IFN-gamma treatment of cultured monocyte-derived macrophages from variant patient $\mathrm{RaJ}$ increased the steady state level of RNA transcripts from the X-CGD gene $\sim 5$ - to 10-fold. The amount of hybridization to X-CGD probe (upper bands) on Northern blot rose from a barely detectable level (right panel, right lanes) up to a prominent band (right panel, left lanes) $\sim 5 \%$ the density of the signal detected in RNA from normal IFN-gamma-treated macrophages (right panel). Simultaneous hybridization of the nitrocellulose filter with a probe for phosphoglycerate kinase (42) (lower bands) demonstrated nearly equal expression of that constitutively expressed gene in all lanes. Additional hybridization bands below the primary, $\sim$ 5-kilobase (kb); X-CGD signal are consistently observed 
CGD

CONTROL

PMN

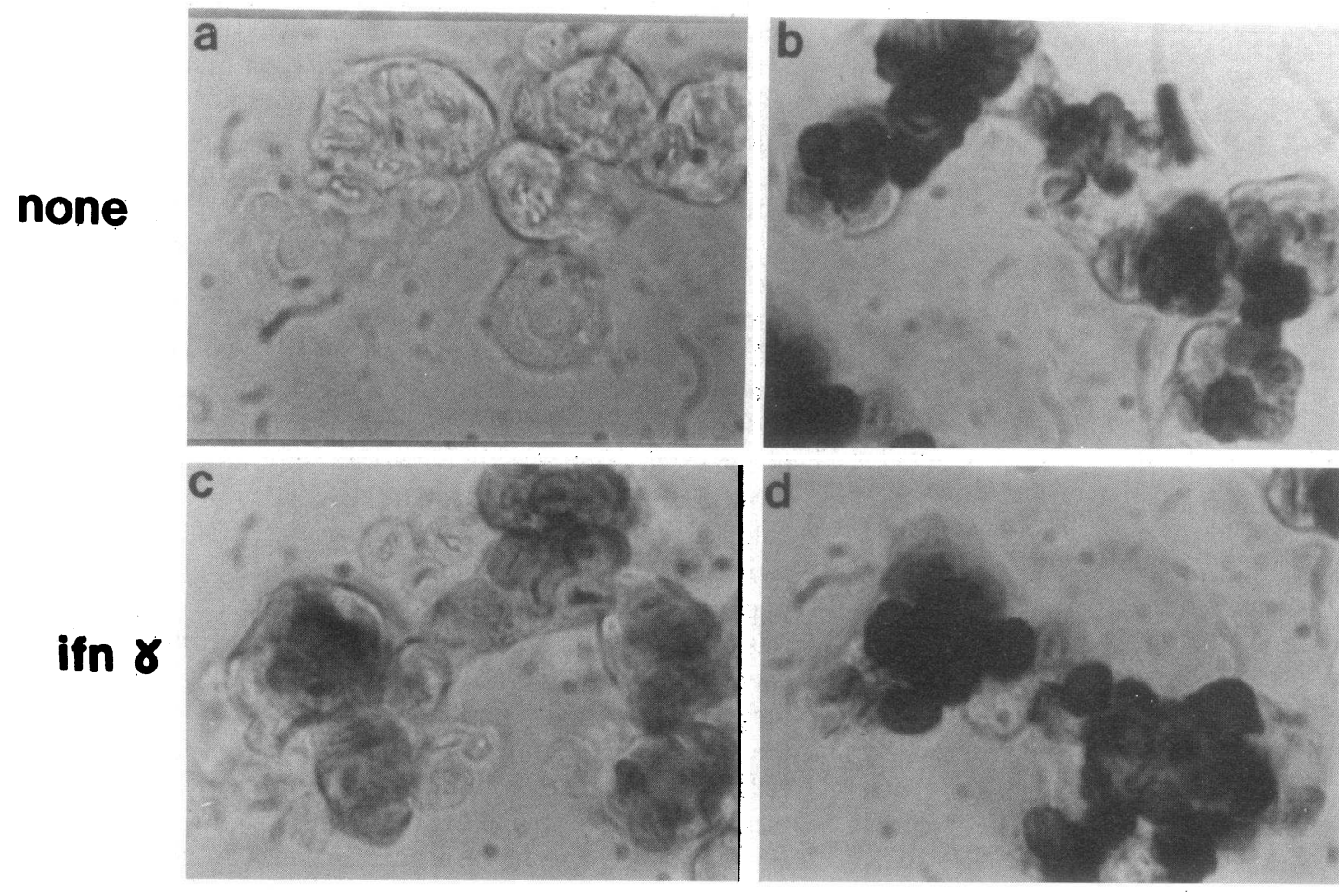

\section{MO}

none
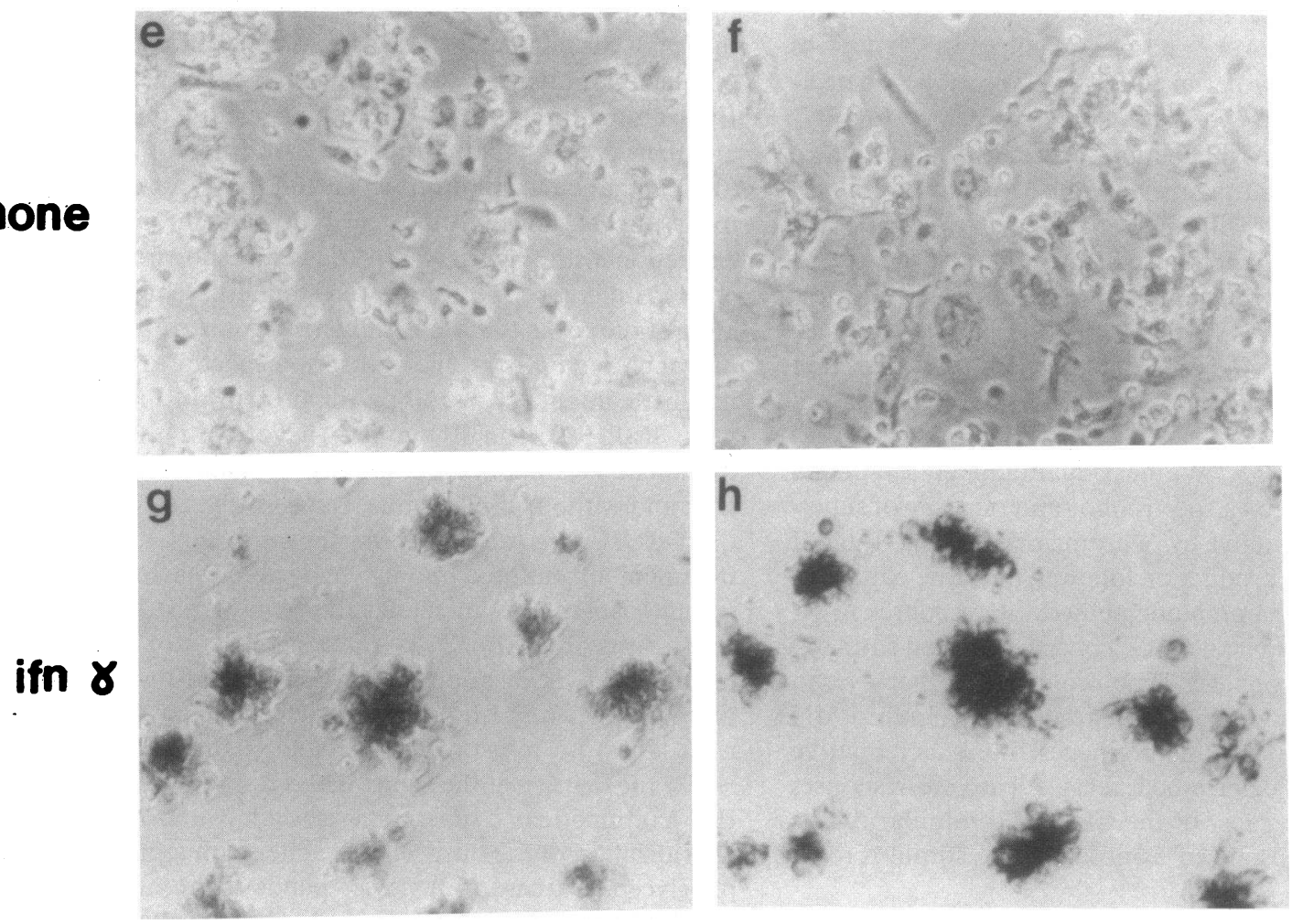
Table II. PMA-stimulated Superoxide Production by CGD and Normal Phagocytes

\begin{tabular}{|c|c|c|c|c|c|}
\hline & \multirow[b]{2}{*}{ Patient } & \multicolumn{2}{|l|}{ PMN } & \multicolumn{2}{|l|}{ Macrophages } \\
\hline & & $-\mathrm{IFN} \gamma$ & $+\mathrm{IFN} \gamma$ & - IFN $\gamma$ & $+\mathrm{IFN} \gamma$ \\
\hline & & nmol $\mathrm{O}_{2} / 5 \mathrm{~min}$ per $10^{6} \mathrm{cells}$ & nmol $\mathrm{O}_{2} / 5 \mathrm{~min}$ per $10^{6} \mathrm{cells}$ & nmol $O_{2} / 5$ min per $10^{6}$ cells & nmol $O_{2} / 5$ min per $10^{6}$ cells \\
\hline \multicolumn{6}{|c|}{ X-linked CGD } \\
\hline \multirow[t]{3}{*}{ Variant } & RaJ & $1.7 \pm 0.4^{*}$ & $3.8 \pm 0.3$ & ND & ND \\
\hline & ReJ & $3.3 \pm 0.6^{*}$ & $8.2 \pm 1.0$ & $<0.7$ & 5.3 \\
\hline & $\mathbf{R Q}$ & $<0.7$ & 1.5 & $<0.7$ & 1.6 \\
\hline \multirow[t]{3}{*}{ Classic } & TB & $<0.7$ & $<0.7$ & $<0.7$ & $<0.7$ \\
\hline & MD & $<0.7$ & $<0.7$ & $<0.7$ & $<0.7$ \\
\hline & JW & $<0.7$ & $<0.7$ & $<0.7$ & $<0.7$ \\
\hline \multicolumn{6}{|c|}{ Autosomal CGD } \\
\hline Classic & LN & $<0.7$ & $<0.7$ & $<0.7$ & $<0.7$ \\
\hline Normal & & $17.8 \pm 2.1^{*}$ & $19 \pm 3.8$ & $7.0 \pm 1.1^{*}$ & $13.1 \pm 1.3$ \\
\hline
\end{tabular}

Superoxide generation was measured by an assay of superoxide dismutase-inhibitable cytochrome $c$ reduction, as described in Methods. Results represent the means of duplicate determinations, except where expressed as means \pm SEM for triplicate (ReJ's PMN) or quadruplicate (normal PMN and macrophages). IFN $\gamma$, IFN-gamma. ${ }^{*} P<0.05$ by paired $t$ test.

with the X-CGD probe and may represent $m R$ NAs with alternative patterns of splicing.

\section{Discussion}

The respiratory burst plays a major role in the antitumor and microbicidal activity of phagocytes $(1,2)$. IFN-gamma, a product of $T$ cells and natural killer cells, enhances the respiratory burst capacity in both human and murine macrophages (44); nonimmune interferons and some products of tumor cells have the opposite effect $(45,46)$. In this study we show that the respiratory burst in phagocytes from three patients with $\mathrm{X}$ linked CGD is enhanced by the addition of IFN-gamma. The low, but detectable, level of phagocyte superoxide-generating activity in these patients, thus classified as CGD variants, probably represents the upper end of a spectrum of oxidase activity in the disease.

Single cell analysis of PMN revealed a homogeneous increase in NBT reduction rather than a responding subpopulation. No response to IFN-gamma was observed in phagocytes from patients with no detectable baseline respiratory burst activity (so-called classic X-linked CGD) or from patients with autosomal recessive CGD, with or without baseline respiratory burst activity. The effect of IFN-gamma required at least 40-60 min incubation for PMN and $36 \mathrm{~h}$ for macrophages. Quantitative measurement of superoxide generation confirmed the findings of the NBT reduction assay, and indicated the IFN-gamma-induced augmentation to be two- to threefold in PMN and two- to eightfold in macrophages.

The mechanism by which IFN-gamma augments superoxide generation by normal and X-CGD phagocytes is not known. Analysis of the kinetics of superoxide generation by
NADPH oxidase showed that interferon treatment increases the $V_{\max }$ of the enzyme, but has little effect on the abnormally low substrate affinity (high $\mathrm{K}_{\mathrm{m}}{ }^{\text {app }}$ ). The initial kinetic abnormality of these cells is characteristic of phagocytes that produce only low levels of reactive oxygen intermediates, such as normal resident macrophages and PMN from patients with so-called variant CGD $(23-25,27,28)$. Treatment of macrophages with IFN-gamma produces an increase in superoxide production, accompanied by a decrease in the $\mathrm{K}_{\mathrm{m}}{ }^{\text {app }}$ without much change in the $\mathrm{V}_{\max }$ of the oxidase (30). The different pattern of kinetic response to IFN-gamma observed in the present study suggests that in X-CGD granulocytes it increases the number of active enzyme molecules per cell, but does not render them functionally normal. This discrepancy may arise from the residual CGD defect or from the difference in cell types examined. The polypeptide encoded by the X-CGD gene (for which the transcript is induced) is the larger ( $90 \mathrm{kd}$ ) of two proteins in the cytochrome $b_{559}$ heterodimer (18) isolated from membranes of activated neutrophils. It thus constitutes only one component of the NADPH oxidase complex. An increase in this one part, not balanced by another component (e.g., the cytochrome heme moiety, which might not be stable in the absence of the 90 -kd glycoprotein) could theoretically produce such a defect. In fact, the absence of a detectable cytochrome $b$ spectrum in IFN-gamma-induced CGD cells suggests that the partial restoration of X-CGD gene transcription (and presumably of its protein product) does not lead to equivalent incorporation of heme into the cytochrome $b_{559}$. The finding of interferon-induced superoxide-generating activity at $40 \%$ the normal rate in these cells further implies that the resultant NADPH oxidase complex is capable of electron transport (albeit abnormally) through pathways independent of the heme
Figure 1. Effect of IFN-gamma on NBT reduction by PMN and macrophages $(\mathbf{M} \phi)$ from X-linked CGD and normal subjects. PMAstimulated NBT slides were prepared for PMN (top, $a-d$ ) and macrophages (bottom, $e-h$ ) from X-linked CGD patient $\mathrm{RaJ}$ (left; $a, c, e$, $g$ ) and a normal control (right; $b, d, f, h)$. PMN had been incubated for $3 \mathrm{~h}$ and macrophages for $4 \mathrm{~d}$ in the absence $(a, b, e, f)$ or presence $(c, d, g, h)$ of IFN-gamma. Cultured wells were photographed at magnifications of 100 for PMN $(a-d)$ and 40 for macrophages $(e-h)$. Dark formazan deposits indicate sites of NBT reduction. 


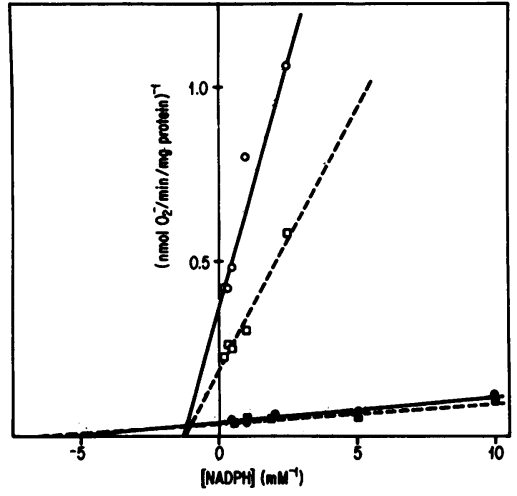

Figure 2. LineweaverBurk plots of NADPH oxidase activity from normal and $\mathrm{X}$-linkedCGD (RaJ) granulocytes, incubated with or without IFN-gamma. The reciprocal of particulate fraction NADPH dependent superoxide generation (ordinant) was plotted against the reciprocal of NADPH concentration (abcissa) as described in

Methods. Each point represents the mean of two experiments, each performed with triplicate determinations. (-० -) Represent oxidase from CGD cells; (- ---$)$, oxidase from CGD cells treated with IFN-gamma; ( $\bullet-)$, oxidase from normal cells; and (- - - -), oxidase from normal cells treated with IFN-gamma.

or for which small, undetectable amounts of heme are sufficient.

IFN-gamma treatment increased the very low steady state level of RNA transcripts from the $\mathrm{X}$ chromosome CGD gene (17) up to one that was 5\% that in normal macrophages. $\mathrm{X}$-CGD gene expression also increases two- to fivefold in normal monocyte-derived macrophages incubated with IFNgamma (Newburger, P. E., S. H. Orkin, and R. A. B. Ezekowitz. Unpublished data). This cytokine therefore appears to up-regulate expression of the X-CGD gene in both normal and CGD macrophages, either by increasing gene transcription or through posttranslational stabilization of mRNA.

However, the proportional rates of superoxide production in treated CGD cells compared with normal cells still appear to be greater than the proportional steady state levels of X-CGD transcripts. This discrepancy suggests that NADPH oxidase enzyme activity is a non-linear function of the level of X-CGD RNA and its protein product, so that small increases in functional RNA transcripts produce major changes in cell function. Alternatively (or additionally), IFN-gammá may increase

Table III. Effect of IFN-Gamma on $V_{\max }$ and $K_{m}{ }^{a p p}$ of NADPH Oxidase from Variant CGD and Normal PMN

\begin{tabular}{|c|c|c|}
\hline & $\mathbf{V}_{\max }$ & $\mathbf{K}_{\mathrm{m}} \mathbf{4 0 0}$ \\
\hline & nmol $O_{2}^{-} /$min per $\mathrm{mg}$ protein & $m M N A D P H$ \\
\hline \multicolumn{3}{|l|}{ Variant CGD } \\
\hline \multicolumn{3}{|l|}{ RaJ } \\
\hline -IFN-gamma & 2.7 & 0.77 \\
\hline +IFN-gamma & 5.0 & 0.56 \\
\hline \multicolumn{3}{|l|}{ ReJ } \\
\hline -IFN-gamma & 3.7 & 0.49 \\
\hline +IFN-gamma & 6.8 & 0.57 \\
\hline \multicolumn{3}{|l|}{ Normal } \\
\hline -IFN-gamma & 27.8 & 0.14 \\
\hline +IFN-gamma & 27.1 & 0.12 \\
\hline
\end{tabular}

Results were calculated by Lineweaver-Burk (37) analysis of triplicate (normal), duplicate (RaJ), or single (ReJ) experiments, as described in Methods.

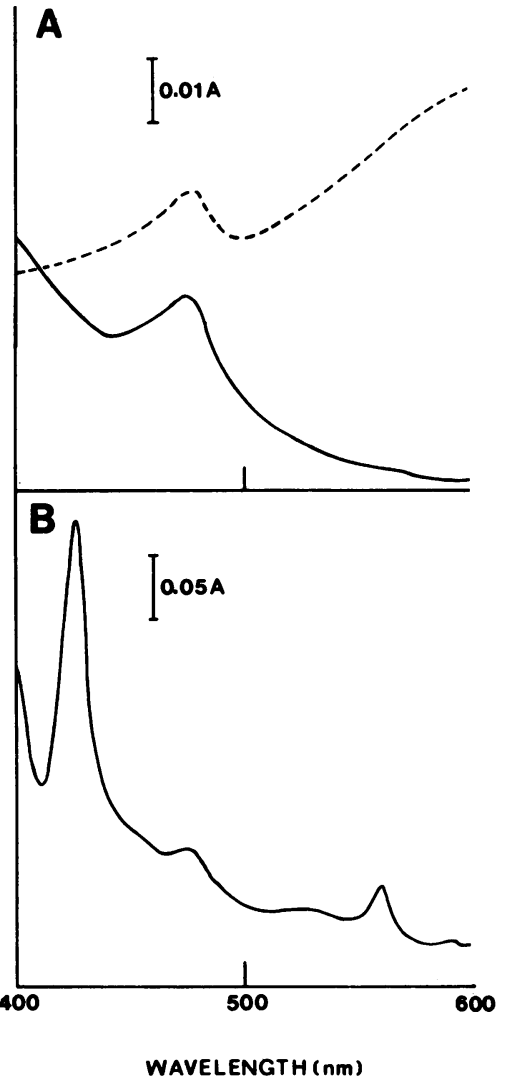

NADPH oxidase activity by posttranslational mechanisms (e.g., cell priming $[6,47])$ that could increase the apparent efficacy of a partially disabled oxidase. Definition of the precise mutations in the X-CGD gene from IFN-gamma-responsive and -unresponsive patients should provide insight into the molecular basis of the cellular and clinical defects in the disorder. The range of residual phagocyte oxidase activity observed in the variant CGD patients suggests that they do not

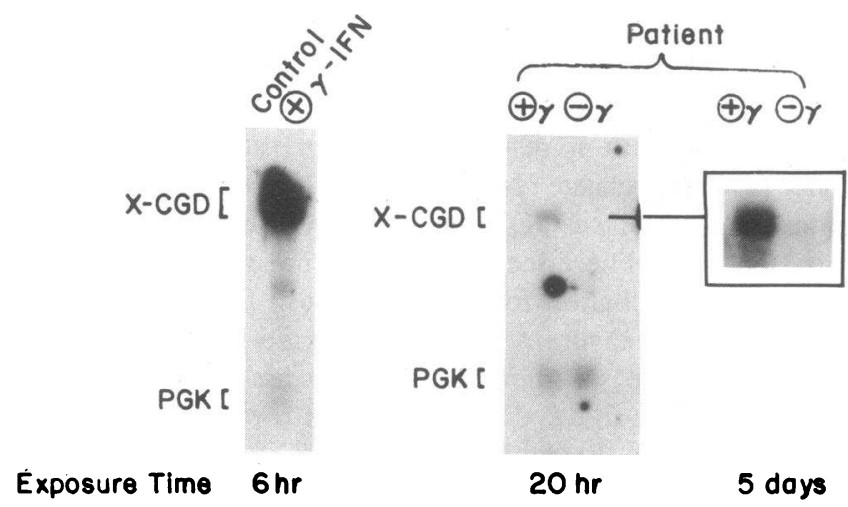

Figure 4. Expression of X-CGD and phosphoglycerate kinase gene transcripts in normal and X-linked CGD phagocytes. Total cell RNA $(10 \mu \mathrm{g})$ from normal macrophages (left), cultured with IFN-gamma, and from CGD patient ReJ's macrophages (right), cultured with or without IFN-gamma as indicated, was examined on Northern blot for X-CGD (11) and phosphoglycerate kinase (47) gene sequences, as described in Methods. "X-CGD" and "PGK" indicate the 5- and 2-kb bands of their respective transcripts. Exposure times for the autoradiographs were $6 \mathrm{~h}$ for the left, $20 \mathrm{~h}$ for the right, and $5 \mathrm{~d}$ for the inset. 
represent a homogeneous subclassification of the disease, but rather a spectrum akin to the $\beta^{+}$thalassemias.

Systemic IFN-gamma therapy has been used to augment hydrogen peroxide secretion by monocytes in patients with malignancy (48). Further, local subcutaneous IFN-gamma therapy can partially correct the systemic defect in monocyte peroxide production in lepromatous leprosy (49). These studies provide a precedent for systemic use of IFN-gamma that may eventually be applicable to the subset of X-linked CGD patients whose cells respond in vitro. This approach would represent a unique opportunity to apply in vitro molecular findings to the pharmacologic modulation of gene expression in human disease.

\section{Acknowledgments}

We thank Dr. D. G. Nathan, Dr. S. E. Lux, and Dr. O. S. Platt for stimulating discussions; Drs. E. O'Rourke and V. Popeo for initial referral of patient RaJ; Mary E. Ferriter, Cheryl Speier, and Constance Whitney for their technical assistance; Madeleine Gilmore for blood collection and handling; and the patients and their families for their enthusiastic cooperation.

This work was supported by The Socha Memorial Fund for Chronic Granulomatous Research, by a Child Health Research grant from the Charles H. Hood Foundation, and by National Institutes of Health grants AI-23768, CA-38325, and HD-18661. This work was performed during the tenure of an Established Investigatorship (Dr. Newburger) of the American Heart Association. Dr. Orkin is an investigator of the Howard Hughes Medical Institute.

\section{References}

1. Nathan, C. F. 1985. Regulation of macrophage oxidative metabolism and antiparasitic activity. In Mononuclear Phagocytes: Characteristics, Physiology, and Function. R. van Furth, editor. Martinus Nijhoff Publishers, Dordrecht, Netherlands. 411-432.

2. Babior, B. M. 1984. Oxidants from phagocytes: agents of defense and destruction. Blood. 64:959-966.

3. Cohen, H. J., and M. E. Chovaniec. 1978. Superoxide generation by digitonin-stimulated guinea pig granulocytes. A basis for a continuous assay for monitoring superoxide production and for the study of the activation of the generating system. J. Clin. Invest. 61:1081-1087.

4. McPhail, L. C., and R. Snyderman. 1983. Activation of the respiratory burst enzyme in human polymorphonuclear leukocytes by chemoattractants and other soluble stimuli. Evidence that the same oxidase is activated by different transductional mechanisms. J. Clin. Invest. 72:192-200.

5. McPhail, L. C., C. C. Clayton, and R. Snyderman. 1984. The NADPH oxidase of human polymorphonuclear leukocytes. Evidence for regulation by multiple signals. J. Biol. Chem. 259:5768-5775.

6. Zimmerli, W., B. Seligmann, and J. I. Gallin. 1986. Exudation primes human and guinea pig neutrophils for subsequent responsiveness to the chemotactic peptide $N$-formylmethionylleucylphenylalanine and increases complement component $\mathrm{C} 3 \mathrm{bi}$ receptor expression. J. Clin. Invest. 77:925-933.

7. Ward, P. A., and E. L. Becker. 1968. The deactivation of rabbit neutrophils by chemotactic factor and the nature of the activatable esterase. J. Exp. Med. 127:693-709.

8. Baehner, R. L., and D. G. Nathan. 1967. Leukocyte oxidase: defective activity in chronic granulomatous disease. Science (Wash. DC). 155:835-836.

9. Curnutte, J. T., D. M. Whitten, and B. M. Babior. 1974. Defective superoxide production by granulocytes from patients with chronic granulomatous disease. N. Engl. J. Med. 290:593-597.

10. Tauber, A. I., N. Borregaard, E. R. Simons, and J. Wright.
1983. Chronic granulomatous disease: a syndrome of phagocyte oxidase deficiencies. Medicine (Baltimore). 62:286-309.

11. Donowitz, G. R., and G. L. Mandell. 1983. Clinical presentation and unusual infections in chronic granulomatous disease. $A d v$. Host Def. Mech. 3:55-76.

12. Mills, E. L., and P. G. Quie. 1983. Inheritance of chronic granulomatous disease. Adv. Host Def. Mech. 3:25-54.

13. Segal, A. W., A. R. Cross, R. C. Garcia, N. Borregaard, N. H. Valerius, J. F. Soothill, and O. T. G. Jones. 1983. Absence of cytochrome b-245 in chronic granulomatous disease. A multicenter European evaluation of its incidence and relevance. $N$. Engl. J. Med. 308:245-251.

14. Ohno, Y., E. S. Buescher, R. Roberts, J. A. Metcalf, and J. I. Gallin. 1986. Reevaluation of cytochrome $b$ and flavin adenine dinucleotide in neutrophils from patients with chronic granulomatous disease and description of a family with probable autosomal recessive inheritance of cytochrome b deficiency. Blood. 67:1132-1138.

15. Segal, A. W. 1985. Variations on the theme of chronic granulomatous disease. Lancet. i:1378-1382.

16. Segal, A. W., O. T. G. Jones, D. Webster, and A. C. Allison. 1978. Absence of a newly described cytochrome $b$ from neutrophils of patients with chronic granulomatous disease. Lancet. ii:446-449.

17. Royer-Pokora, B., L. M. Kunkel, A. P. Monaco, S. C. Goff, P. E. Newburger, R. L. Baehner, F. S. Cole, J. T. Curnutte, and S. H. Orkin. 1986. Cloning the gene for an inherited disorder-chronic granulomatous disease - on the basis of its chromosomal location. Nature (Lond.). 322:32-38.

18. Dinauer, M., C. A. Parkos, A. J. Jesaitis, and S. H. Orkin. 1987. Identification of the in vivo protein encoded by the gene mutated in X-linked chronic granulomatous disease (X-CGD). Clin. Res. 35:598. (Abstr.)

19. Parkos, C. A., R. A. Allen, C. G. Cochrane, and A. J. Jesaitis. 1987. Purified cytochrome $b$ from human granulocyte plasma membrane is comprised of two polypeptides of 91,000 and 22,000 relative molecular weights. J. Clin. Invest. 80:732-742.

20. Segal, A. W. 1987. Absence of both cytochrome b245 subunits from neutrophils in X-linked chronic granulomatous disease. Nature (Lond.). 326:88-91.

21. Curnutte, J. T., P. J. Scott, R. Kuver, and R. Berkow. 1986. NADPH oxidase activation cofactor: partial purification and absent activity in a patient with chronic granulomatous disease. Clin. Res. 34:455. (Abstr.)

22. Segal, A. W., P. G. Heyworth, S. Cockcroft, and M. M. Barrowman. 1985. Stimulated neutrophils from patients with autosomal recessive chronic granulomatous disease fail to phosphorylate a $\mathrm{M}_{\mathrm{r}}-44,000$ protein. Nature (Lond.). 316:547-549.

23. Lew, P. D., F. S. Southwick, T. P. Stossel, J. C. Whitin, E. R. Simons, and H. J. Cohen. 1981. A variant of chronic granulomatous disease: deficient oxidative metabolism due to a low-affinity NADPH oxidase. $N$. Engl. J. Med. 305:1329-1333.

24. Seger, R. A., L. Tiefenauer, T. Matsunaga, A. Wildfeuer, and P. E. Newburger. 1983. Chronic granulomatous disease due to granulocytes with abnormal NADPH oxidase activity and deficient cytochrome b. Blood. 61:423-428.

25. Shurin, S. B., H. J. Cohen, J. C. Whitin, and P. E. Newburger. 1983. Impaired granulocyte superoxide production and prolongation of the respiratory burst due to a low-affinity NADPH-dependent oxidase. Blood. 62:564-571.

26. Styrt, B., and M. S. Klempner. 1984. Late-presenting variant of chronic granulomatous disease. Pediatr. Infect. Dis. 3:556-559.

27. Borregaard, N., A. R. Cross, T. Herlin, O. T. G. Jones, A. W. Segal, and N. H. Valerius. 1983. A variant form of X-linked chronic granulomatous disease with normal nitroblue tetrazolium slide test and cytochrome b. Eur. J. Clin. Invest. 13:243-247.

28. Newburger, P. E., F. W. Luscinskas, T. Ryan, C. J. Beard, J. Wright, O. S. Platt, E. R. Simons, and A. I. Tauber. 1986. Variant chronic granulomatous disease: modulation of the neutrophil defect by severe infection. Blood. 68:914-919. 
29. Nathan, C. F., and S. Tsunawaki. 1986. Secretion of toxic oxygen products by macrophages: regulatory cytokines and their effects on the oxidase. CIBA Symp. 118:211-230.

30. Cassatella, M. A., V. Della Bianca, G. Berton, and F. Rossi. 1985. Activation by gamma interferon of human macrophage capability to produce toxic oxygen molecules is accompanied by decreased $\mathrm{K}_{\mathrm{m}}$ of the superoxide-generating NADPH oxidase. Biochem. Biophys. Res. Commun. 132:908-914.

31. Berton, G., L. Zeni, N. A. Cassatella, and F. Rossi. 1986. Gamma interferon is able to enhance the oxidative metabolism of human neutrophils. Biochem. Biophys. Res. Commun. 138:12761282.

32. Babior, B. M., and H. J. Cohen. 1981. Measurement of neutrophil function: phagocytosis, degranulation, the respiratory burst, and bacterial killing. In Leukocyte Function. M. J. Cline, editor. Churchill-Livingstone, Inc., New York. 1-38.

33. Ezekowitz, R. A. B., R. B. Sim, G. G. MacPherson, and S. Gordon. 1985. Interaction of human monocytes, macrophages, and polymorphonuclear leukocytes with zymosan in vitro. Role of type 3 complement receptors and macrophage-derived complement. J. Clin. Invest. 76:2368-2376.

34. Suzuki, Y., and R. I. Lehrer. 1980. NADPH oxidase activity in human neutrophils stimulated with phorbol myristate acetate. J. Clin. Invest. 66:1409-1418.

35. Newburger, P. E., C. Speier, N. Borregaard, C. E. Walsh, J. C. Whitin, and E. R. Simons. 1984. Development of the superoxide-generating system during differentiation of the HL-60 promyelocytic leukemia cell line. J. Biol. Chem. 259:3771-3776.

36. Light, D. R., C. Walsh, A. M. O'Callaghan, E. J. Goetzl, and A. I. Tauber. 1981. Characteristics of the cofactor requirements for the superoxide-generating NADPH oxidase of human polymorphonuclear leukocytes. Biochemistry. 20:1468-1476.

37. Lineweaver, H., and D. Burk. 1934. The determination of enzyme dissociation constants. J. Am. Chem. Soc. 56:658-666.

38. Pember, S. O., B. L. Heyl, J. M. Kinkade Jr., and J. L. Lambeth. 1984. Cytochrome b558 from (bovine) granulocytes. Partial purification from Triton X-114 extracts and properties of the isolated cytochrome. J. Biol. Chem. 259:10590-10595.

39. Ginsburg, D., R. I. Handin, D. T. Bonthron, T. A. Donlon, G. A. P. Bruns, S. A. Latt, and S. H. Orkin. 1985. Human von Wille- brand factor: isolation of complementary DNA clones and chromosomal location. Science (Wash. DC). 228:1401-1406.

40. Maniatis, T., E. F. Fritsch, and J. Sambrook. 1982. Molecular Cloning: A Laboratory Manual. Cold Spring Harbor Laboratory, Cold Spring Harbor, NY. 545 pp.

41. Feinberg, A. P., and B. Vogelstein. 1983. A technique for radiolabeling DNA restriction endonuclease fragments to high specific activity. Anal. Biochem. 132:6-13.

42. Michelson, A. M., A. F. Markham, and S. H. Orkin. 1983. Isolation and DNA sequence of a full-length cDNA for human $\mathrm{X}$ chromosome-encoded phosphoglycerate kinase. Proc. Natl. Acad. Sci. USA. 80:472-476.

43. Nathan, C. F., H. W. Murray, M. E. Wiebe, and B. Y. Rubin. 1983. Identification of interferon gamma as the lymphokine that activates human macrophage oxidative metabolism and antimicrobial activity. J. Exp. Med. 158:670-689.

44. Nathan, C. F. 1983. Mechanisms of macrophage antimicrobial activity. Trans. R. Soc. Trop. Med. Hyg. 77:620-630.

45. Ezekowitz, R. A. B., M. Hill, and S. Gordon. 1986. Interferon alpha/beta selectively antagonizes down-regulation of mannosyl-fucosyl receptors on activated macrophages by interferon gamma. Biochem. Biophys. Res. Commun. 136:737-744.

46. Szuro-Sudol, A., H. W. Murray, and C. F. Nathan. 1983. Suppression of macrophage antimicrobial activity by a tumor cell product. J. Immunol. 131:384-387.

47. Shalaby, M. R., B. B. Aggarwal, E. Rinderknecht, L. P. Svedersky, B. S. Finkle, and M. A. Palladino Jr. 1985. Activation of human polymorphonuclear neutrophil functions by interferon gamma and tumor necrosis factors. J. Immunol. 135:2069-2073.

48. Nathan, C. F., C. R. Horowitz, J. de la Harpe, S. Vadhan-Raj, S. A. Sherwin, H. F. Oettgen, and S. E. Krown. 1985. Administration of recombinant interferon gamma to cancer patients enhances monocyte secretion of hydrogen peroxide. Proc. Natl. Acad. Sci. USA. 82:8686-8690.

49. Nathan, C. F., G. Kaplan, W. Levis, A. Nursat, M. Wetmer, S. Sherwin, C. K. Job, C. R. Horwitz, R. M. Steinman, and Z. A. Cohn. 1986. Local and systemic effects of intradermal recombinant interferon gamma in patients with lepromatous leprosy. N. Engl. J. Med. 315:6-11. 